\title{
Znak i interpretacja. Czy możliwa jest semiotyka hermeneutyczna?
}

ABSTRACT. Januszkiewicz Michał, Znak i interpretacja. Czy możliwa jest semiotyka hermeneutyczna? [Sign and interpretation. Is hermeneutical semiotics possible?]. „Przestrzenie Teorii” 28. Poznań 2017, Adam Mickiewicz University Press, pp. 129-138. ISSN 1644-6763. DOI 10.14746/pt.2017.28.5.

The article "Sign and interpretation" is an attempt to answer the question of the possibility of the existence of hermeneutic semiotics. The discussion relates essentially to problems such as sign and interpretation. The author analyzes the selected threads of thought of Charles Sanders Peirce, showing their similarity to the hermeneutics of Heidegger and Gadamer.

KEYWORDS: semiotics, hermeneutics, sign, interpretation

\section{Semiotyka i hermeneutyka - zbieżna rozbieżność}

Nowoczesny paradygmat teorii literatury (przynajmniej w Polsce) określić można mianem formalno-strukturalno-semiotyczno-fenomenologicznego $^{1}$. Zrodził się on na gruncie przełomu antypozytywistycznego. Pomimo że hermeneutyka, o czym już nieraz pisałem, miała swój wielki udział w tym przełomie, znalazła się poza wspomnianym paradygmatem, czy nawet usytuowana w opozycji wobec niego. W konsekwencji zawsze przeciwstawiano hermeneutyce (nie bez słuszności) formalizm i strukturalizm, ale i semiotykę czy fenomenologię. Nie jestem przekonany (a nawet wręcz przeciwnie) o zasadności opozycji fenomenologia-hermeneutyka. Warto zapytać: czy byłoby rzeczą zasadną upierać się przy opozycji semiotyka-hermeneutyka? Zwłaszcza jeżeli przez semiotykę pojmiemy semiotykę kultury. Postacią szczególną byłby w tym kontekście Michaił Bachtin, filozof i teoretyk kultury i literatury, znakomicie łączący obie tradycje filozoficzne ${ }^{2}$. Tym razem interesować mnie będzie tu jednak semiotyka Charlesa Sandersa Peirce'a (1839-1914)³ , której niektóre wątki pozwolą rozwinąć wstępną odpo-

${ }^{1}$ Sformułowanie to pochodzi od Ryszarda Nycza. Zob. jego Tekstowy świat. Poststrukturalizm a wiedza o literaturze, Warszawa 1993.

${ }^{2}$ Przypadek „,semiotyki hermeneutycznej” Bachtina omawiałem w rozdziale mojej książki (Kim jestem ja, kim jesteś ty? Etyka, tożsamość, rozumienie, Poznań 2012) zatytułowanym Bachtinowska antropologia stowa $i$ jej implikacje dla humanistyki.

${ }^{3} \mathrm{~W}$ sprawie semiotyki Peirce'a uwagę zwracają prace przede wszystkim Hanny Buczyńskiej-Garewicz, badaczki, która dokonała jedynego w Polsce wyboru myśli Peirce’a (Ch.S. Peirce, Wybór pism semiotycznych, tłum. R. Mirek, A.J. Nowak, Warszawa 1997). Bardzo ważne 
wiedź na pytanie o możliwość semiotyki hermeneutycznej. Jednakże winien jestem w tym miejscu pewne wyjaśnienie. Zaproponowany pomysł ma zaledwie wstępny, czy raczej przedwstępny charakter, bo odnosi się on raczej do pewnych intuicji, kwestii przyczynkarskich. Nie może więc on rościć sobie pretensji do holistycznego ujęcia problemu. Rzecz domagałaby się dopiero rozwinięcia. Dlatego też chciałbym podkreślić, że interesują mnie jedynie niektóre wybrane i szkicowo zarysowane wątki semiotyki Peirce'owskiej, które traktuję jako punkt wyjścia do odpowiedzi na pytanie o możliwość przekładu tejże semiotyki (czy raczej właśnie wyselekcjonowanych z niej momentów) na język refleksji hermeneutycznej. Ta druga z kolei także ujęta zostaje w pewnych ogólnych rysach, z wyróżnieniem wątku Heideggerowskiego. Wydaje się bowiem, że w sposób szczególny możliwe jest spotkanie semiotyki Peirce'a i hermeneutyki Heideggera. Miejscem tego spotkania jest, jak się wydaje, interpretacja jako doświadczenie bycia-w-świecie.

Zacznijmy jednak od rozróżnienia semiotyki i hermeneutyki.

Przedmiotem zainteresowania semiotyki (czy jak mówią inni: semio-

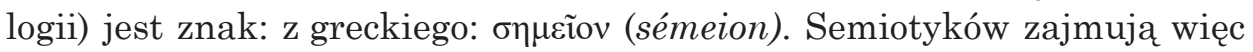
pytania o to, czym sa znaki, jak sa generowane, czy w jaki sposób wchodza w relacje z ludźmi i światem. Czy znaki są przede wszystkim domeną języka naturalnego (jak postrzegał je językoznawca Ferdinand de Saussure ${ }^{4}$ ), czy stanowią istotę rozmaitych, szerzej (niż język naturalny) rozumianych kodów (jak widział to m.in. Charles Sanders Peirce)? Z kolei przedmiotem zainteresowań hermeneutyki sa rozumienie i interpretacja. Hermeneuci pytają więc o to, czym jest rozumienie i co właściwie się z nami dzieje, gdy rozumiemy. Czy rozumienie (z interpretacją jako jego wykształconą forma) dotyczy jedynie danych na gruncie języka naturalnego tekstów, czy może szerzej: odnosi się do samej egzystencji i kwestii kultury?5. Już w odniesieniu do tych pytań wyraźnie widać, że zarówno semiotyka, jak i hermeneutyka za najważniejsze uznają pytania o język - rozumiany węziej bądź szerzej6.

miejsce zajmuje tu również monografia Buczyńskiej-Garewicz: Semiotyka Peirce’a, Warszawa 1994.

${ }^{4}$ Zob. F. de Saussure, Kurs językoznawstwa ogólnego, tłum. K. Kasprzyk, Warszawa 2002, s. 89-94.

${ }^{5}$ Zob. A. Wierciński, Phronesis as the Mediation Between Logos and Ethos: Rationality and Responsibility, [w:] Hermeneutic Rationality/La rationalité herméneutique, ed. by M.L. Portocarrero, L.A.Umbelino, and A. Wierciński, Münster 2012; tenże, Hermeneutics Between Philosophy and Theology. The Imperative to Think Incommensurable, Berlin 2010, s. $316-317$.

${ }^{6}$ Język jest nie tylko wyróżnionym obszarem badań hermeneutyki, ale ją samą warunkuje, jest podstawowym wymiarem hermeneutycznej refleksji dotyczącej rozumienia i interpretacji. Szczególnym tego wyrazem są prace Hansa-Georga Gadamera, który zagadnieniom języka poświęca najważniejszą część Prawdy i metody, ale i szereg innych wypowiedzi. Zob. 
Jednakże semiotycy pytają przede wszystkim: czym jest to, co znaczy i w jaki sposób znaczy podczas gdy hermeneutyka woli zapytać: co to właściwie ma znaczyć? To pytanie być może brzmi napastliwie (znane jest w hermeneutyce przekonanie, że interpretacja to rodzaj gwałtu), jednak chciałbym utrzymywać - wbrew temu, co sądzi na przykład Susan Sonntag - że poszukiwanie znaczenia nie musi być formą przemocy ${ }^{7}$. Znaki są przecież (dawane i czynione) po to, by je odczytywać/interpretować. Takie przekonanie, jak się wydaje, pogodzić może semiotyków i hermeneutów. Byłoby również rzeczą niewybaczalną, gdyśmy pominęli historyczne związki pomiędzy semiotyką i hermeneutyka, które poświadczają to, o czym mowa. Pozwolę odnieść się tylko do najbardziej ewidentnych przykładów. Czy Hermeneutyka Arystotelesa nie jest w gruncie rzeczy pierwszym podręcznikiem do semiotyki?? Czy tego samego nie możemy powiedzieć o jakże ważnej pracy Boecjusza Komentarz do „Hermeneutyki” Arystotelesa? ${ }^{9}$. I inny przykład, którego pominąc nie wolno, to De doctrina christiana św. Augustyna, dzieło, w którym semiotyka i hermeneutyka zostały z sobą powiązane ${ }^{10}$. Problematyce semiotycznej poświęca autor księgę drugą (to tu po raz pierwszy dokonane zostają rozróżnienia na znaki naturalne i konwencjonalne, czy właściwe i przenośne), która stopniowo rozwija się już w problematykę hermeneutyczną (najgłębiej zaprezentowaną w księdze trzeciej), dotyczącą interpretacji Pisma Świętego.

\section{Pojęcie znaku}

Przedmiotem moich kilku uwag chciałbym uczynić koncepcję znaku Peirce'a w kontekście postawionego wcześniej pytania o możliwość hermeneutycznego „przesunięcia” semiotyki. Uważam, że takie „przesunięcie” jest możliwe na gruncie kilku wskazanych przez filozofa kwestii: 1) interpretanta (rozumianego jako aspekt semantyczny znaku i jego interpretacja); 2) użytkownika znaku (aspekt pragmatyczno-egzystencjalny znaku); wreszcie 3) koncepcji uprzedniości znaku w stosunku do interpretacji (ten

H.-G. Gadamer, Prawda i metoda. Zarys hermeneutyki filozoficznej, tłum. B. Baran, Kraków 1993; tenże, Język i rozumienie, tłum. P. Dehnel, B. Sierocka, Warszawa 2003; tenże, Rozum, stowo, dzieje, tłum. M. Łukasiewicz, Warszawa 2000.

${ }^{7}$ Zob. tytułowy esej Susan Sontag w jej: Przeciw interpretacji $i$ inne eseje, tłum. M. Pasicka, A. Skucińska, D. Żukowski, Kraków 2012.

${ }^{8}$ Arystoteles, Hermeneutyka, tłum. K. Leśniak, [w:] Arystoteles, Dzieła wszystkie, Warszawa 1990, t. 1.

${ }^{9}$ Boecjusz, Komentarz do „Hermeneutyki” Arystotelesa, Kęty 2010, t. 1-2.

${ }^{10}$ Św. Augustyn, De doctrina christiana. O nauce chrześcijańskiej, tłum. J. Sulowski, Warszawa 1989. 
aspekt chciałbym określić hermeneutycznym). Zanim przejdziemy do definicji znaku, warto zauważyć, że zdaniem filozofa ma on charakter triadyczny. Na znak składają się mianowicie: reprezentamen, interpretant i obiekt (referent) ${ }^{11}$. Należy zauważyć, że pojęcie reprezentamenu występuje u Peirce'a w dwóch znaczeniach: epistemologicznym - wówczas odnosi się do znaku jako takiego; oraz ontologicznym, to jest związanym z samym sposobem istnienia znaku. W tym drugim sensie reprezentamen to po prostu materialny nośnik znaku, który można by utożsamić z desaussurowskim signifiant (znaczącym), jest forma, jaką przyjmuje znak. Znak wystapić może przecież pod postacią rozmaitych form: fotografii czy rysunku, śladów na śniegu, symptomów przeziębienia, wypowiedzianych czy napisanych słowach, mowie ciała czy w sygnalizacji drogowej. Obiekt (referent) jest z kolei tym, do czego znak się odnosi lub co zastępuje: fotografia odnosi się do tego, co na niej zaprezentowane, ślady na śniegu do tego, kto je pozostawił, słowa do znaczeń itd., itp. Warto zauważyć, że Peirce nie był naiwnym realistą i nie miał na myśli w pełni autonomicznych obiektów realnych. Filozof podkreślał, że człowiek nie dysponuje absolutną i bezpośrednia wiedza na temat tego, jak się rzeczy mają. Peirce'owski obiekt to zatem nic innego jak element znaku, ściśle skorelowany z reprezentamenem $\mathrm{i}$ interpretantem. Interpretant to z kolei ten element znaku, który łączy reprezentamen i obiekt poprzez znaczenie. W tym sensie można by sądzić, że pojęcie interpretanta pokrywa się częściowo z pojęciem signifié Ferdinanda de Saussure'a. Jeżeli zatem znak w ogóle znaczy, jeżeli ma znaczenie, to właśnie jako interpretant, który skorelowany jest ze sposobem dania znaku (representamenem) i jego obiektem ${ }^{12}$.

Filozof definiował znak na różne sposoby, rozwijał też i reinterpretował własne pojęcia. Przyjrzyjmy się dwóm spośród wielu sformułowanych przez Peirce'a definicji znaku, a następnie wypowiedzi o rozjaśniającym te definicje charakterze, przyjmującej postać twierdzenia:

Znak jest czymś, co zastępuje dla kogoś jakiś przedmiot pod jakimś względem lub w jakiejś zdolności, jest czymś, co zmusza coś innego (jego interpretanta), aby odnosił się do przedmiotu, do którego sam się odnosi ${ }^{13}$.

${ }^{11}$ Ch.S. Peirce, Wybór pism semiotycznych..., s. 131.

${ }^{12}$ Pytanie o możliwość przekładu semiotyki Peirce'owskiej na desaussurowską domaga się niezależnego omówienia, sprawa nie jest bowiem prosta. Nie wszyscy skłonni są przyznać, aby taki przekład był możliwy. Na przykład Gerard Deledalle twierdzi wręcz, że systemy te sa całkowicie niekompatybilne, bowiem de Saussure operuje ujęciem dualistycznym, a Peirce - triadycznym. Zob. G. Deledalle, Peirce's Philosophy of Signs. Essays in Comparative Semiotics, Bloomington and Indianapolis 2000, s. 55.

${ }^{13}$ Ch.S. Peirce, Collected Writings, ed. Ch. Hartshorne, P. Weiss, A.W. Burks, Cambridge 1931-1958. t. 2 , § 303. 
Znak, czyli reprezentamen, jest to coś, co komuś zastępuje coś innego pod pewnym względem lub w pewnej roli. Zwraca się do kogoś, czyli wytwarza w umyśle tej osoby równoważny, a może i bardziej rozwinięty znak. Znak, który został wytworzony, nazywam interpretantem pierwszego znaku. Znak zastępuje coś, mianowicie swój przedmiot. Zastępuje ten przedmiot nie pod każdym względem, ale w odniesieniu do pewnego rodzaju idei, która czasami nazywałem podstawa reprezentamenu ${ }^{14}$.

I wreszcie istotne wyjaśnienie-twierdzenie:

Coś reprezentuje coś, czyli znajduje się w takiej relacji do czegoś innego, że przez pewien umysł traktowane jest dla określonych celów tak, jak gdyby było owym innym ${ }^{15}$.

Przywołane definicje ukazują istotę znaku jako zastępowanie jakiegoś przedmiotu (rzeczy). Znak stanowi więc reprezentację rzeczy, ale nie w sensie jej odwzorowania czy kopiowania, ale reprezentowania, które polega na tym, że zastępowana rzecz pod względem jakiejś własności lub zdolności ma udział w reprezentującym ją znaku. Pod jakim względem jednak znak (reprezentamen) może reprezentować rzecz? Aby odpowiedzieć na to pytanie, należałoby przywołać zaproponowany przez filozofa trojaki podział znaków na ikony, indeksy i symbole ${ }^{16}$. Przypomnijmy tylko. Ikony (znaki ikoniczne czy podobizny - likenesses) to znaki imitujące, a więc na przykład zdjęcia czy rysunki, które stanowią podobizny tego, co przedstawiaja. Można by więc powiedzieć, że ikona reprezentuje rzecz pod względem podobieństwa. Z kolei do indeksów (zwanych też symptomami czy oznakami) należa przede wszystkim (choć nie tylko) znaki naturalne, jak ślady na śniegu, wskazujące na kogoś, kto je pozostawił; dym, świadczący o palącym się ogniu, ból głowy jako oznaka zmęczenia itp. W tym przypadku znak reprezentuje rzecz pod względem przyczynowości (ból głowy wskazuje na zmęczenie jako swoją przyczynę). Ale indeksy to nie tylko symptomy, lecz wszelkie znaki, których istota jest wskazywanie (bycie wskazówka), albo, mówiąc inaczej, są to znaki, które odnosza się do rzeczy ze względu na wskazywanie. W tym sensie do indeksów należeć będą drogowskaz czy zaimek wskazujacy ${ }^{17}$. Wreszcie symbol. Wśród symboli wymienić należy znaki językowe (słowa), mowę ciała i gestów, znaki drogowe, sygnalizację morską czy biały dym unoszący się z Watykanu. Jak widać, symbole mają charakter arbitralny i odnoszą się do rzeczy pod względem przyjętych konwencji. W ten sposób zinterpretować można te fragmenty podanych

\footnotetext{
${ }^{14}$ Tenże, Wybór pism semiotycznych..., s. 131.

${ }_{15}$ Tamże, s. 149.

${ }^{16}$ Tamże, s. 138-139.

${ }^{17}$ Tenże, What is a sign? (tu zob.: paragraf 3), <https://www.marxists.org/reference/ subject/philosophy/works/us/peirce1.htm> [dostęp: 24.10.2016].
} 
definicji, które ujmują znak w sensie jego zastępowania, względnie wskazywania rzeczy (obiektu).

Dużo większym wyzwaniem okazuje się problematyka interpretanta. To pojęcie niewątpliwie wieloznaczne, różnie (re)interpretowane przez samego filozofa. Warto też zauważyć, że bywa ono mylnie rozumiane i sprowadzane do interpretatora. Jednakże interpretant to nie interpretator ${ }^{18}$. Przywołane wyżej definicje znaku wskazują różne znaczenia tego słowa. Po pierwsze, interpretant rozumieć można jako element triadycznej struktury znaku. W tym sensie, jak już to zostało powiedziane wcześniej, interpretant to po prostu znaczenie znaku albo, jak powiedziałby Peirce, interpretant bezpośredni - to, na co znak bezpośrednio wskazuje czy co wyraża w jakimś najogólniejszym sensie. Przykład: jabłko to po prostu jabłko, czyli owoc; mówiąc inaczej: to, co wszyscy mniej więcej podobnie rozumiemy na podstawie tożsamości przedmiotu. Po drugie, interpretant może być pojmowany w szerszym sensie. Chodzi tu o sytuację, w której znak wytwarza w umyśle jego użytkownika pewien inny, ekwiwalentny lub bardziej rozbudowany znak, za pomoca którego ów użytkownik odnosi się do znaku pierwszego - to w terminologii Peirce'a interpretant dynamiczny ${ }^{19}$. Przykład: jabłko to typowy popularny europejski owoc; albo: jabłko to zdrowie; albo wreszcie: jabłko to owoc z drzewa poznania dobra i zła, którym Ewa skusiła Adama itd., itp. W tym oto miejscu możemy, choć z pewną ostrożnościa, mówić o hermeneutycznym przemieszczeniu problematyki znaku. Oto bowiem interpretant rozumiany $\mathrm{w}$ tym drugim znaczeniu to nic innego jak interpretacja. Inaczej: interpretant to nie tylko znaczenie znaku, lecz również inny znak (interpretant), za sprawą którego możemy rozumieć właśnie znaczenie tego znaku. Owo znaczenie znaku (interpretant) staje się zrozumiałe na gruncie innego interpretanta. Ten inny interpretant nie ma jednak charakteru izolowanego, lecz sam przynależeć musi przecież do triadycznej struktury innego znaku, który może być rozumiany za pośrednictwem kolejnego interpretanta i tak ad infinitum ${ }^{20}$. Ten proces znaczeniotwórczy, proces interpretacji, określa filozof mianem sign-action albo semiosis. W ten oto sposób filozof nierozerwalnie wiąże znak z pojęciem rozumienia (interpretacji). Jeżeli bowiem coś jest znakiem, to musi być jakoś rozumiane, to znaczy musi mieć swojego innego interpretanta, który pojmować należy jako interpretację, rozpoznanie i wyjaśnienie znaku. Peirce był jednak nie tylko semiotykiem, ale i pragmatysta. Nie chciał zgodzić się na proces nieograniczonej semiozy.

${ }^{18}$ Zob. A. Baldy, Przyczynek do Ch.S. Peirce’a koncepcji znaku. „Studia Philosophiae Christianae" 2007, nr 43, s. 129-130.

${ }^{19} \mathrm{~W}$ sprawie interpretanta bezpośredniego i dynamicznego zob. C.S. Peirce, Wybór pism semiotycznych..., s. 116-118. Zob. też A. Baldy, dz. cyt., s. 129-130.

${ }^{20}$ Zob. Ch.S. Peirce, Wybór pism semiotycznych..., s. 162. 
Dlatego zaproponował pojęcie interpretanta ostatecznego ${ }^{21}$, który umożliwia zakończenie procesu semiozy za sprawą decyzji (bynajmniej nie subiektywnej) co do „ukierunkowanego działania” 22 .

Problematyka semiotyczna spotyka się z hermeneutyczną nie tylko w odniesieniu do pojęcia interpretanta/interpretacji, ale i w kontekście przywoływanego w obu definicjach znaku jego użytkownika. Znak nie tylko zastępuje coś pod jakimś względem, lecz jest również znakiem dla kogoś. Ten ktoś to oczywiście interpretator. Kontynuator Peirce'a, Charles Morris, mówi $\mathrm{w}$ związku z relacją znaku do interpretatora o pragmatycznym wymiarze znaku. Z hermeneutycznego punktu widzenia mówić tu możemy również o wymiarze egzystencjalnym. Znaczenie znaku (interpretant dynamiczny) nie ma charakteru czysto obiektywnego, lecz możliwe jest za sprawa jego interpretatora. W refleksji hermeneutycznej - podobnie jak w semiotyce Peirce'a - również podkreślamy, że interpretacja jest zawsze czyjaś, nie daje się jej oderwać od bycia-w-świecie, które zawsze już jest, jak pokazuje to Heidegger, rozumiejące. Rozumienie (interpretacja) to przecież wyróżniony sposób bycia. Hermeneutyka pojmuje tekst (zespół zorganizowanych znaków) czy myśl (w semiotyce Peirce’a myśl jest znakiem, bo przecież odnosi się do czegoś innego niż ona sama; w tym sensie znakiem w szerokim znaczeniu byłoby więc dzieło sztuki - literackiej, filmowej, malarskiej) jako wyzwanie do odpowiedzi. Odpowiedzia jest interpretacja. Podobnie jak w przypadku nieograniczonej semiozy, interpretacja, jak powiada Gadamer, stanowi dialog, w którym nigdy nie może paść ostatnie słowo, a porozumienie (interpretant ostateczny) nie jest dane raz na zawsze. Co jednak nie oznacza, że nie jest ono możliwe.

\section{Prymat interpretacji}

W pierwszym zdaniu artykułu zatytułowanego What is a sign? (1894) pytanie o znak uznaje filozof za fundamentalne, gdyż, jak zauważa, ,wszelkie myślenie stanowi interpretację jakiegoś rodzaju znaków” (,all reasoning

${ }^{21}$ Zob. P. Broszkiewicz, Charlesa Sandersa Peirce’a koncepcja znaku względem Peirce'owskiego pragmatyzmu, „Słupskie Studia Filozoficzne” 2012, nr 11, s. 199-200. Badaczka zauważa: „w koncepcji Peirce'a związek między danym znakiem a jego interpretantem jest zawsze związkiem opartym na przekonaniu, w wyniku tego związku właśnie odbiorca znaku ma nawyk wiązania go z jego interpretantem. Nawyk ten Peirce określał mianem ostatecznego logicznego interpretanta (the ultimate logical interpretant) i uznawał go za znaczenie znaku. Ów ostateczny logiczny interpretant to interpretant, który sam nie będąc już znakiem, lecz określonym wzorem działania, nie wymaga już dalszego interpretanta, przeto kończy proces semiozy, zatrzymuje regres w nieskończoność w rozumieniu znaku, będąc znaczeniem znaku".

${ }^{22}$ Zob. Ch.S. Peirce, Wybór pism semiotycznych..., s. 118. 
is an interpretation of signs of some kind") ${ }^{23}$. W pismach Peirce'a odnajduję jednak myśl, nad którą jak sądzę, warto się bliżej pochylić. Myśl, na którą należy odpowiedzieć hermeneutycznie. Filozof powiada, że myślimy jedynie za pomocą znaków ${ }^{24}$ oraz że „Nic nie jest znakiem, dopóki nie zostanie zinterpretowane jako znak" (,Nothing is a sign unless it is interpreted as a sign" ${ }^{25}$. Otóż uważam, że przywołana myśl ma znaczenie rewolucyjne. Nie chodzi tu bowiem jedynie o to, że każdy znak domaga się interpretacji. To już wiemy i nie jest to myśl szczególnie odkrywcza. Odkrywczość leży gdzie indziej. Zdanie to mówi bowiem: interpretacja poprzedza znak (oczywiście nie w chronologicznym, ale logicznym sensie). To zaskakujące stwierdzenie. Zaskakujące dlatego, że przywykliśmy sądzić właśnie na odwrót: że oto najpierw rzuceni zostaliśmy w świat znaków, a potem dopiero zmuszeni zostaliśmy do ich interpretacji. Tymczasem Peirce mówi: aby coś było znakiem, musi być dopiero zinterpretowane jako znak. Tym samym uznaje filozof interpretację za podstawową aktywność ludzką. Jak zauważa Hanna Buczyńska-Garewicz:

Znak rozumiany triadycznie jako interpretant (poprzedzajacego go znaku) i jako obiekt interpretacji (interpretowany przez następujący po nim znak) ujawnia złożoną naturę procesu interpretacji. [...] Interpretacja jest czynnościa, nie jest możliwa inaczej niż jako nieustająca aktywność. Jest jednak interpretacja także poddawaniem się czynności, jest stanem domagającym się nowej interpretacji. Ta dwoista natura interpretacji stanowi jej istotę ${ }^{26}$.

Co to jednak znaczy, że coś może być dopiero zinterpretowane jako znak? $\mathrm{Na}$ to pytanie wydają się możliwe dwie biegunowo przeciwne odpowiedzi. Pierwsza brzmi zachowawczo (jednak w pozytywnym sensie tego słowa), druga - radykalnie. Obie jednak odpowiedzi pozwalają zrozumieć zarówno egzystencjalny wymiar ludzkiego bycia-w-świecie, jak i miejsce człowieka w przestrzeni kultury. Odpowiedź pierwsza brzmiałaby zatem: Nic nie jest znakiem, dopóki nie zostanie rozpoznane jako znak. Bycie-w-świecie, by trzymać się tej hermeneutyczno-egzystencjalnej formuły, oznacza konieczność oswajania przez nas świata, poszukiwania zadomowienia. Jak zauważa najważniejszy przedstawiciel nowoczesnej hermeneutyki, Martin Heidegger, w naszym „zatroskaniu, tzn. w byciu-w-świecie samego jestestwa, dana jest już z góry potrzeba «znaku»; narzędzie to przejmuje wyraźne i łatwo wyko-

${ }^{23}$ Tenże, What is a sign? (tu zob. paragraf 3), https://www.marxists.org/reference/subject/ philosophy/works/us/peirce1.htm [dostęp: 24.10.2016].

${ }^{24}$ Tenże, Wybór pism semiotycznych..., s. 162.

${ }^{25}$ Tenże, Collected Writings..., § 172. Zob. też: D. Chandler, Semiotics. The Basics, London-New York 2007, s. 13.

${ }^{26}$ Zob. H. Buczyńska-Garewicz, Poszukiwanie sensu semiotyki, „Teksty” 1980, nr 2, s. 186. 
nalne podawanie kierunków. Znak utrzymuje przeglądowo wykorzystywane strony wyraźnie otwarte - każdorazowe «dokąd» przynależenia, wchodzenia, wnoszenia lub przynoszenia"27.

Ludzkie bycie-w-świecie, jak powie Heidegger, jest zawsze ukierunkowane ${ }^{28}$. Żyjemy wśród znaków, które powinniśmy umieć rozpoznawać. To otaczające nas metafory, symbole i alegorie, znaki (teksty) kultury; to także kulturowe normy czy ideały osobowości. Umiejętność poruszania się wśród znaków już w kulturze danych, znaków, których wciąż musimy się uczyć, zakotwicza nas w tradycji kultury i historii, pozwala nam pojąc własna tożsamość. Taki jest sens tego, co kulturoznawcy nazywają enkulturacja, a socjologowie - socjalizacja. Odpowiedź druga brzmi zupełnie inaczej: Nic nie jest znakiem, dopóki nie zostanie uznane za znak. To odpowiedź wyrażona w duchu konstruktywistycznym. Bycie-w-świecie nie tylko oznacza rozpoznawanie i uczenie się znaków, ale też ich wytwarzanie - inwencję. Człowiek przynależy do kultury także i w ten sposób, że ją tworzy. Ten wymiar egzystencji zaświadcza o wolności człowieka, która oznacza tu: wolność interpretacji. Zauważyć wszak trzeba, że obie odpowiedzi mogą zostać wypaczone, to znaczy zrozumiane niewłaściwie. Zgoda na bycie wśród wyłącznie rozpoznanych i gotowych znaków okazać się może świadectwem dogmatycznego skostnienia. Z kolei absolutyzacja ludzkiej inwencji wieść może nieuchronnie do samowoli, wykorzenienia z kulturowego dziedzictwa i utratę poczucia tożsamości.

Jeśli chcielibyśmy pytać o możliwość spotkania między semiotyką i hermeneutyka, to, jak sądzę, upatrywać by jej można w komplementarnym i nierozerwalnym zwiazku znaku i interpretacji. Rozumienie natury interpretacji okazuje się kluczowe dla zrozumienia tego, w jaki sposób człowiek wchodzi w relacje ze światem za pośrednictwem znaków. Peirce'owska koncepcja znaku, jak widać to wyraźnie, nie ma charakteru abstrakcyjnego, ale zakłada rozumiejąca interpretację i interpretatora. Interpretator okazuje się podstawowym ogniwem procesu semiosis. Znak jest przecież zawsze adresowany do kogoś, kto dokonuje jego przekładu na inne znaki. Ale także wszelkie nasze doświadczenie, to, co nazywamy byciem-w-świecie, jest już przecież także zmediatyzowane poprzez znaki. Zarazem zauważmy: w przeciwieństwie do de Saussure'a, który zamykał człowieka w sieci odsyłających do siebie nawzajem i różnicujących się znaków, Peirce, podobnie jak dzieje się to w refleksji hermeneutycznej, pojmuje znaki i interpretacje jako przestrzeń, za sprawą której świat się przed nami dopiero udostępnia i otwiera. Znaki nie zamykają przed nami świata, lecz dopiero czynia go otwartym i możliwym.

${ }^{27}$ M. Heidegger, Bycie i czas, tłum. B. Baran, Warszawa 1994, s. 154.

${ }^{28}$ Tamże, s. 154. 
Takimi znakami jesteśmy także my sami - dla siebie nawzajem. Doświadczenie późnej nowoczesności nie powinno od tego problemu abstrahować, lecz przeciwnie, z większa jeszcze jaskrawością zdawać z niego sprawę. Czy nie żyjemy dziś pośród rozmazanych i niejasnych znaków, których nie potrafimy interpretować? Czy sami nie staliśmy się dziś nieczytelni, a przez to - nieufni i zrezygnowani? Czy jest jeszcze do czego się odnosić? Czy, aby odnaleźć zadomowienie, nie powinniśmy przeto poszukiwać sposobów, aby uczynić siebie i świat na nowo czytelnymi?

\section{BIBLIOGRAFIA}

Arystoteles, Hermeneutyka, tłum. K. Leśniak, [w:] tegoż, Dzieła wszystkie, Warszawa 1990, t. 1 , s. $127-251$.

Augustyn, De doctrina christiana. O nauce chrześcijańskiej, tłum. J. Sulowski, Warszawa 1989.

Baldy A., Przyczynek do Ch.S. Peirce'a koncepcji znaku, „Studia Philosophiae Christiane” 2007, nr 43, s. 119-131.

Boecjusz, Komentarz do „Hermeneutyki” Arystotelesa, Kęty 2010, t. 1-2.

Broszkiewicz P., Charlesa Sandersa Peirce’a koncepcja znaku względem Peirce'owskiego pragmatyzmu, „Słupskie Studia Filozoficzne” 2012, nr 11, s. 191-203.

Buczyńska-Garewicz H., Poszukiwanie sensu semiotyki, „Teksty” 1980, nr 2, s. 183-187.

Gadamer H.-G., Język i rozumienie, tłum. P. Dehnel, B. Sierocka, Warszawa 2003.

Gadamer H.-G., Prawda i metoda. Zarys hermeneutyki filozoficznej, tłum. B. Baran, Kraków 1993.

Gadamer H.-G., Rozum, słowo, dzieje, tłum. M. Łukasiewicz, Warszawa 2000.

Heidegger M., Bycie i czas, tłum. B. Baran, Warszawa 1994.

Januszkiewicz M,, Kim jestem ja, kim jesteś ty? Etyka, tożsamość, rozumienie, Poznań 2016.

Nycz R,, Tekstowy świat. Poststrukturalizm a wiedza o literaturze, Warszawa 1993.

Peirce Ch.S., Collected Writings, ed. C. Hartshorne, P. Weiss. A.W. Burks, t. 2, Cambridge 1931-1958.

Peirce Ch.S., What is a sign?, <https://www.marxists.org/reference/subject/philosophy/ works/us/peirce1.htm> [dostęp: 24.10.2016].

Peirce Ch.S., Wybór pism semiotycznych, tłum. R. Mirek, Warszawa 1997.

Saussure F. de, Kurs językoznawstwa ogólnego, Warszawa 2002.

Sontag S., Przeciw interpretacji i inne eseje, tłum. M. Pasicka, A. Skucińska, D. Żukowski, Kraków 2012.

Wierciński A., Phronesis as the Mediation Between Logos and Ethos: Rationality and Responsibility, [w:] Hermeneutic Rationality/La rationalité herméneutique, ed. M.L. Portocarrero, L.A. Umbelino, A. Wierciński, Münster 2012, s. 73-86. 